International Journal of Biological Sciences

ISSN 1449-2288 www.biolsci.org 2007 3(4):237-241

Research Paper

(C) Ivyspring International Publisher. All rights reserved

\title{
Tyrosine Sulfation of Statherin
}

\author{
C. Kasinathan ${ }^{1}$, N. Gandhi' ${ }^{1}$, P. Ramaprasad ${ }^{1}$, P. Sundaram ${ }^{2}$, N. Ramasubbu ${ }^{1}$ \\ 1. Oral Biology, NJ Dental School, University of Medicine and Dentistry of New Jersey, Newark, NJ 07103-2400, USA. \\ 2. Current address: Recombinant Technologies LLC, 5 Science Park at Yale, New Haven, CT 06511, USA.
}

Correspondence to: Dr. C. Kasinathan, Oral Biology, NJ Dental School, University of Medicine and Dentistry of New Jersey, 110 Bergen Street, Newark, NJ 07103-2400, USA. Tel: 973-972-7426 kasinach@ umdnj.edu

Received: 2006.12.17; Accepted: 2007.02.27; Published: 2007.03.02

Tyrosylprotein sulfotransferase (TPST), responsible for the sulfation of a variety of secretory and membrane proteins, has been identified and characterized in submandibular salivary glands (William et al. Arch Biochem Biophys 1997; 338: 90-96). In the present study we demonstrate the sulfation of a salivary secretory protein, statherin, by the tyrosylprotein sulfotransferase present in human saliva. Optimum statherin sulfation was observed at $\mathrm{pH} 6.5$ and at $20 \mathrm{~mm} \mathrm{MnCl}_{2}$. Increase in the level of total sulfation was observed with increasing statherin concentration. The $K_{m}$ value of tyrosylprotein sulfotransferase for statherin was $40 \mu \mathrm{M}$. Analysis of the sulfated statherin product on SDS-polyacrylamide gel electrophoresis followed by autoradiography revealed ${ }^{35} \mathrm{~S}-$ labelling of a $5 \mathrm{kDa}$ statherin. Further analysis of the sulfated statherin revealed the sulfation on tyrosyl residue. This study is the first report demonstrating tyrosine sulfation of a salivary secretory protein. The implications of this sulfation of statherin in hydroxyapatite binding and Actinomyces viscosus interactions are discussed.

Key words: Saliva, statherin, tyrosine sulfation

\section{Introduction}

Human saliva, which has several components, plays a crucial role not only in diffusion of acids but also in clearance of bacterial adhesion from the oral cavity. The importance of carbohydrate sulfation in the processing of specific salivary glycoproteins [2] and the involvement of these glycoproteins in bacterial aggregating activity has been reported earlier [3]. Therefore, it has been suggested that tyrosine sulfation may also play a role in the biological activity of tyrosine-containing salivary proteins as it has been demonstrated in other proteins [4-8]. Sulfation of tyrosyl residues in cholecystokinin is required for its optimal biological activity [4] and in the case of hirudin, tyrosine sulfation increases the binding efficiency to thrombin [5]. In M31 hybridoma cell line, tyrosine sulfation has been shown to serve as a signal for the secretion of IgG [6]. In p-selectin glycoprotein ligand -1 (PSGL-1), tyrosine sulfation required for its binding to p-selectin [7] and the tyrosine sulfation of chemokine receptor 5 (CCR5) facilitates HIV-1 entry [8]. Although the significance of tyrosine sulfation in these and several other proteins has been studied in detail, its role in salivary protein is yet to be investigated. In naturally occurring substrates of tyrosylprotein sulfotransferase, the sulfated tyrosyl residues are predominantly surrounded by acidic amino acids [9], and the frequency distribution of basic amino acids in these sites is extremely low [10]. In 1992, Lin et al. [11] had shown increased tyrosine sulfation of substrates containing acidic amino acids by TPST. These studies suggest that acidic environments are the important determinants for tyrosine sulfation. Salivary statherin is a 43-residue polypeptide, which is tyrosine-rich and contains 7 tyrosine residues. The peptide also contains a sequence (residues 26-30) required for tyrosine sulfation as suggested by Lin et al., [11] and Bundgard et al., [12]. In this paper, we have examined the sulfation of salivary statherin. The results demonstrate, for the first time, the tyrosine sulfation of a salivary protein, statherin, by the tyrosylprotein sulfotransferase from human saliva.

\section{Materials and Methods}

\section{Materials}

${ }^{35}$ S-3' phosphoadenosine 5'-phosphosulphate (PAPS) $(2 \mathrm{Ci} / \mathrm{mmol})$ was purchased from DuPont New England Nuclear. Poly $\left(\mathrm{Glu}^{6}, \mathrm{Ala}^{3}, \mathrm{Tyr}^{1}\right)$ (EAY) and 5'-AMP were from Sigma-Aldrich. All other reagents were of analytical grade.

\section{Human Saliva}

Unstimulated saliva was obtained from healthy individuals. The saliva was centrifuged at $6,000 \mathrm{rpm}$ for $10 \mathrm{~min}$ and the clear supernatant was used as enzyme source. Protein concentration was estimated by the BCA (No. 23225) protein assay reagent (Pierce Chemical Co.). Statherin was purified from human submandibular-sublingual saliva collected from three male donors as described previously [13]. Amino acid composition, N-terminal sequencing and SDS-PAGE were used to check the purity of statherin. 


\section{Assay of Statherin Sulfation}

The statherin sulfation assay mixture contained the following components: $100 \mu \mathrm{M}$ statherin (acceptor), $5 \mu \mathrm{M}{ }^{35}$ S-PAPS (4000,000 cpm), $10 \mathrm{mM} \mathrm{MnCl}$ ' $20 \mathrm{mM}$ MES, $\mathrm{pH}$ 6.5, and saliva $(100 \mu \mathrm{g})$ in a final volume of $50 \mu \mathrm{l}$. Assays were initiated by the addition of the enzyme and incubated for $30 \mathrm{~min}$ at $37^{\circ} \mathrm{C}$. Controls without statherin were also incubated for $30 \mathrm{~min}$ at $37^{\circ} \mathrm{C}$. Statherin sulfation was obtained by subtracting controls from the total sulfation. The reactions were stopped by spotting $35 \mu \mathrm{l}$ aliquots of the reaction mixture on $2.4 \times 2.4 \mathrm{~cm}$ Whatman No. $3 \mathrm{MM}$ filter paper [1]. The papers were washed three times for 15 min in $10 \%$ trichloroacetic acid/10 $\mathrm{mM} \mathrm{Na}_{2} \mathrm{SO}_{4}$ and rinsed for $5 \mathrm{~min}$ in 95\% ethanol. The dried papers were placed in vials containing scintillation solution and counted in a TriCarb-1500 scintillation counter. In experiments involving the analysis ${ }^{35} \mathrm{~S}$-sulfate labeled statherin, the assay volume was increased to $200 \mu 1$. Reactions were stopped by addition of $100 \mu \mathrm{l}$ of a solution containing $6.25 \%$ SDS, $10 \%$ glycerol and $0.005 \%$ bromophenol blue. The samples were processed for SDS-PAGE as described below.

\section{SDS-Polyacrylamide Gel Electrophoresis and Autoradiography}

The separating gels contained $15 \% \quad(\mathrm{w} / \mathrm{v})$ acrylamide, bis(acrylamide) in the ratio of 37.5:1, 0.375 $\mathrm{M}$ Tris- $\mathrm{HCl}, \mathrm{pH} 8.8,0.1 \%$ SDS, $0.026 \%$ TEMED, and $0.026 \%$ ammonium persulfate. The stacking gel contained 3\% acrylamide, bis(acrylamide) in the same ratio as before, $0.125 \mathrm{M}$ Tris- $\mathrm{HCl}, \mathrm{pH} 6.8,0.1 \%$ SDS, $0.05 \%$ ammonium persulfate, and $0.4 \%$ TEMED. Electrophoresis was performed in a Mighty Small gel apparatus (Hoefer Scientific Instruments, San Francisco, CA) at $4^{\circ} \mathrm{C}$ at a constant current of $20 \mathrm{~mA}$ per gel for approximately $1 \mathrm{~h}$. After electrophoresis the gel was stained for $30 \mathrm{~min}$. with Coomassie blue and destained in a solution containing $40 \%$ methanol, $10 \%$ acetic acid. After destaining, the gels were soaked in water for $30 \mathrm{~min}$ and then in $1 \mathrm{M}$ sodium salicylate for another $30 \mathrm{~min}$. The gels were then dried and autoradiographed at $-70{ }^{\circ} \mathrm{C}$ on Hyper Film B-max (Amersham).

\section{Identification of Tyrosine Sulfate in Statherin}

To determine the radioactive tyrosine-O-sulfate in statherin, the gel containing ${ }^{35} \mathrm{~S}$-sulfate labeled statherin was cut, lyophilized, incubated for $18 \mathrm{~h}$ at $37^{\circ} \mathrm{C}$ in $1 \mathrm{ml}$ of a solution containing $75 \mu \mathrm{g}$ of trypsin, $50 \mathrm{mM}$ ammonium bicarbonate, $\mathrm{pH} 8$, and a trace of phenol red, and then lyophilized again. The lyophilized material was dissolved in $1 \mathrm{ml}$ of $0.2 \mathrm{M}$ $\mathrm{Ba}(\mathrm{OH})_{2}$, and the tubes were evacuated, sealed and incubated for $24 \mathrm{~h}$ at $110^{\circ} \mathrm{C}$. The sample was then centrifuged at $5000 \mathrm{Xg}$ for $20 \mathrm{~min}$. The supernatant was neutralized with $1 \mathrm{~N} \mathrm{H}_{2} \mathrm{SO}_{4}$ using phenol red as $\mathrm{pH}$ indicator and centrifuged at $5000 \mathrm{Xg}$. The supernatant thus obtained was lyophilized and the dry residue was dissolved in 10-20 $\mu \mathrm{l}$ of electrophoresis buffer ( $5 \%$ acetic acid- $0.5 \%$ pyridine),
$\mathrm{pH}$ 3.5. The solution was centrifuged at $5000 \mathrm{Xg}$ for 5 min and applied on plastic-backed cellulose thin-layer sheets. Electrophoresis was performed until the phenol red marker migrated $7-8 \mathrm{~cm}$, i.e., just past the middle of the cellulose sheet. In our electrophoresis system this took about $3 \mathrm{~h}$ at $450 \mathrm{~V}$. The cellulose sheet was dried, and the unlabeled amino acid standards were detected by spraying the cellulose sheet with $1 \%$ ninhydrin in acetone and developing the color at $110^{\circ} \mathrm{C}$ for three minutes. Radioactive tyrosine sulfate spot was detected by autoradiography on Hyper Film B-max (Amersham) at $-70^{\circ} \mathrm{C}$.

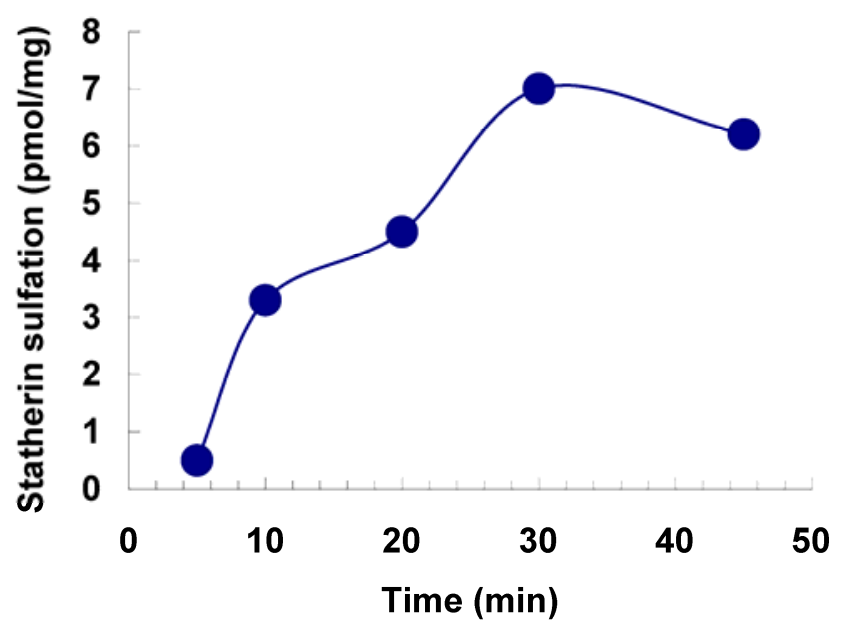

Figure 1. Effect of time on the sulfation of statherin by tyrosylprotein sulfotransferase of human saliva. The statherin sulfation was measured as described under Materials and Methods.

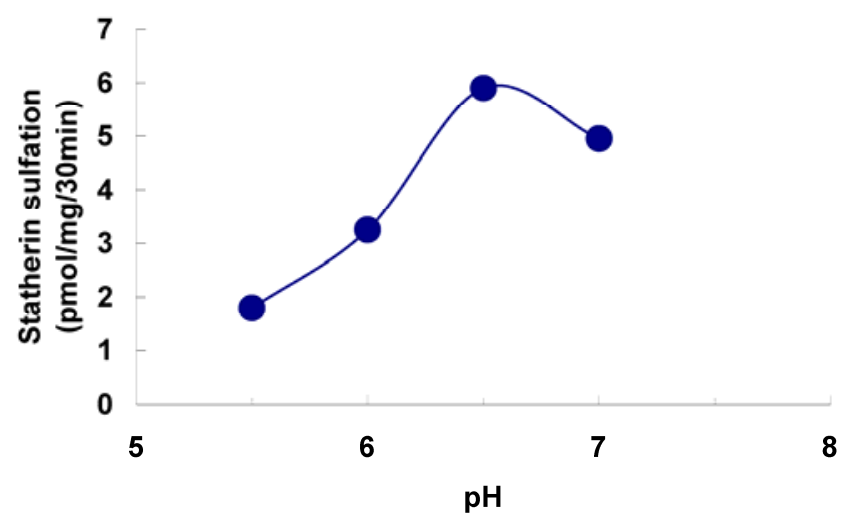

Figure 2. Effect of $\mathrm{pH}$ on the sulfation of statherin by tyrosylprotein sulfotransferase of human saliva. The statherin sulfation was measured as described under Materials and Methods except that the $\mathrm{pH}$ of the assay buffer was varied.

\section{Results and Discussion}

The sulfation of statherin by the tyrosylprotein sulfotransferase present in human saliva was demonstrated using statherin as sulfate acceptor and 
[35S] PAPS as sulfate donor. Effect of time on sulfation of statherin is shown in Fig. 1. The statherin sulfation activity increased with increased incubation time up to $30 \mathrm{~min}$. A $20 \%$ reduction in sulfation level was observed when the reaction was extended for an additional $15 \mathrm{~min}$. The effect of $\mathrm{pH}$ on the sulfation of statherin by salivary tyrosylprotein sulfotransferase is shown in Fig. 2. Using the MES buffer, the $\mathrm{pH}$ optimum for the sulfation of statherin by tyrosylprotein sulfotransferase was attained at $\mathrm{pH} 6.5$. Dependence of statherin sulfation on $\mathrm{MnCl}_{2}$ is illustrated in Fig. 3. Statherin sulfation was detected in the absence of exogenous $\mathrm{MnCl}_{2}$. However, maximum sulfation required $20 \mathrm{mM} \mathrm{MnCl}$. Effect of statherin concentration on statherin sulfation is shown in Fig. 4. The amount of sulfate incorporation into statherin was dependent upon the concentration of exogenous statherin. The sulfation of statherin increased proportionately with increasing concentration of statherin. The tyrosylprotein sulfotransferase has been identified and characterized in several tissues and cells [14] including submandibular salivary glands and human saliva $[15,16]$. The substrate used in these studies was poly-Glu, $\mathrm{Ala}_{3}, \mathrm{Tyr}_{1}$. Comparison of the properties of these reactions to the statherin sulfation reveals that both reactions require $\mathrm{MnCl}_{2}$ and the $\mathrm{pH}$ requirement was in the range of 6 to 6.75 . A $K_{m}$ value $40 \mu \mathrm{M}$ was observed for statherin. The statherin concentration in human saliva is $0.42 \%$ of the total salivary protein [17]. The total endogenous statherin concentration in our assay system is less than $1.6 \%$ of the exogenous statherin added to the assay. Hence, the endogenous statherin present in the saliva will have minimal effect on the $K_{m}$ value reported here. The $K_{m}$ value of $40 \mu \mathrm{M}$ for statherin was higher than the one reported for the artificial substrate poly-Glu ${ }_{6}, \mathrm{Ala}_{3}, \mathrm{Tyr}_{1}$ (Sundaram et al., 1992). Like the natural substrate statherin, a higher $K_{m}$ value was observed earlier for the cholecystokinin [18].

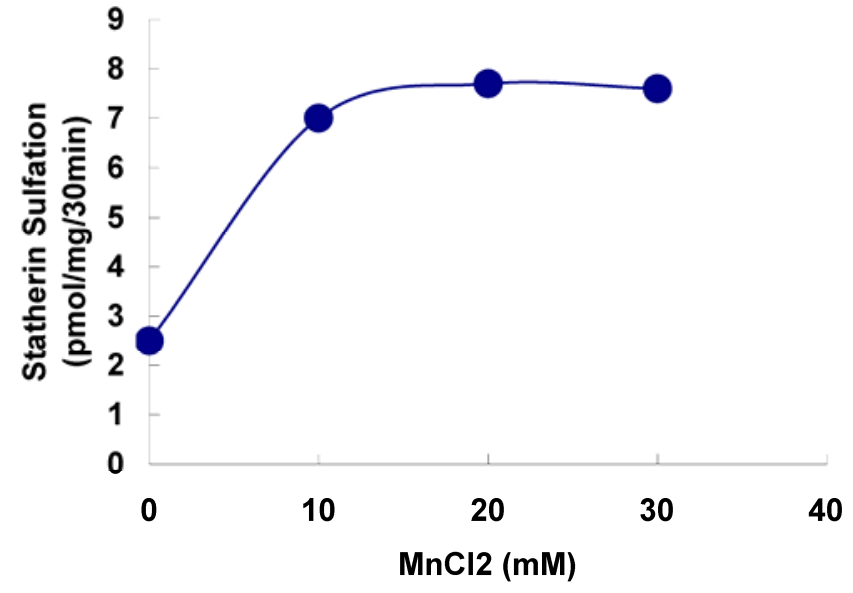

Figure 3. Effect of $\mathrm{MnCl}_{2}$ on the on the sulfation of statherin by tyrosylprotein sulfotransferase of human saliva. The statherin sulfation was measured as described under Materials and Methods except that the $\mathrm{MnCl} 2$ concentration of the assay buffer was varied.
The sulfation of ${ }^{35 S}$-labeled statherin on SDS-PAGE followed by autoradiography is shown in Fig. 5. A major ${ }^{35}$ S-labeled endogenous salivary mucin at the top of the separating gel was observed in all three lanes (unpublished observation). A polypeptide poly-Glu $6, \mathrm{Ala}_{3}, \mathrm{Tyr}_{1}[19]$, which is being used as a substrate for tyrosine sulfation in several studies, was used as a positive control. The autoradiogram depicted in Fig. 5, demonstrate the sulfation of a $5 \mathrm{kDa}$ statherin (lane, 3) and $25 \mathrm{kDa}$ polypeptide poly-Glu, $\mathrm{Ala}_{3}, \mathrm{Tyr}_{1}$ (lane 2). This, together with the above kinetic experiments, clearly demonstrates the sulfation of statherin by TPST. Further analysis was carried out to identify the sulfated amino acid in statherin. As shown in Fig. 6, the sulfation of statherin occurred on tyrosine residues.

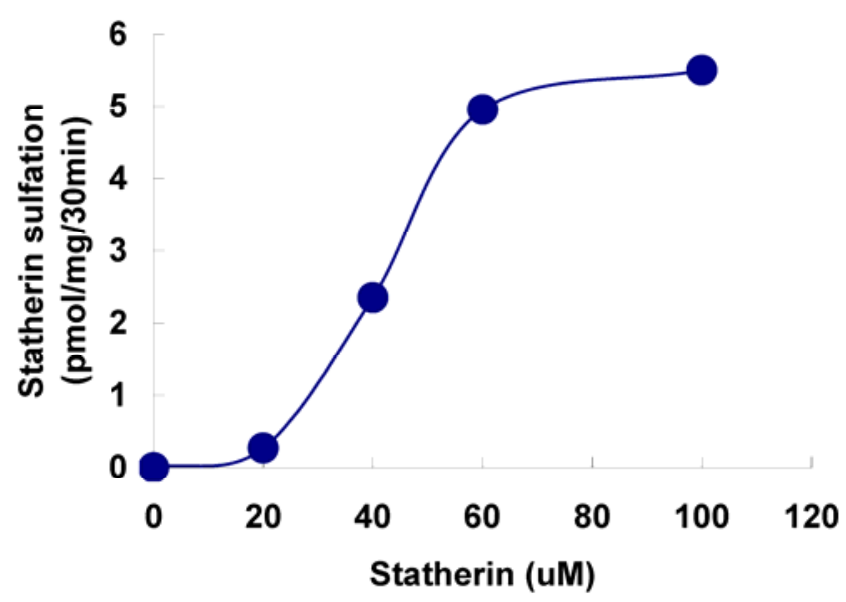

Figure 4. Effect of statherin concentration on the sulfation of statherin by tyrosylprotein sulfotransferase human saliva. The statherin sulfation was measured as described under Materials and Methods.

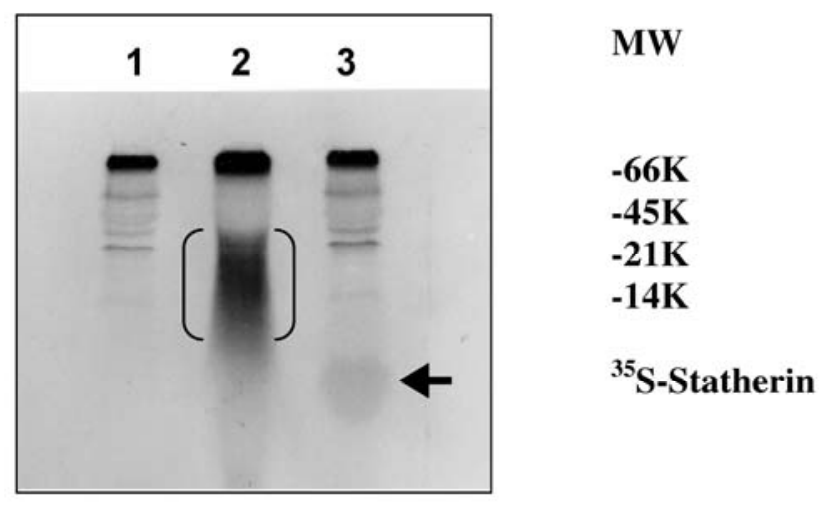

Figure 5. Identification of the ${ }^{35} \mathrm{~S}$ labelled statherin in an autoradiogram of an SDS-polyacrylamide electrophoretic gel. Statherin and poly-Glu ${ }_{6}, \mathrm{Ala}_{3}, \mathrm{Tyr}_{1}$ was sulfated as described under Experimental Procedures. Lane 1, Human saliva; Lane 2, Human Saliva + EAY; Lane 3, Human Saliva + Statherin. EAY sulfation is marked by double bracket. Statherin sulfation is shown by an arrow. 


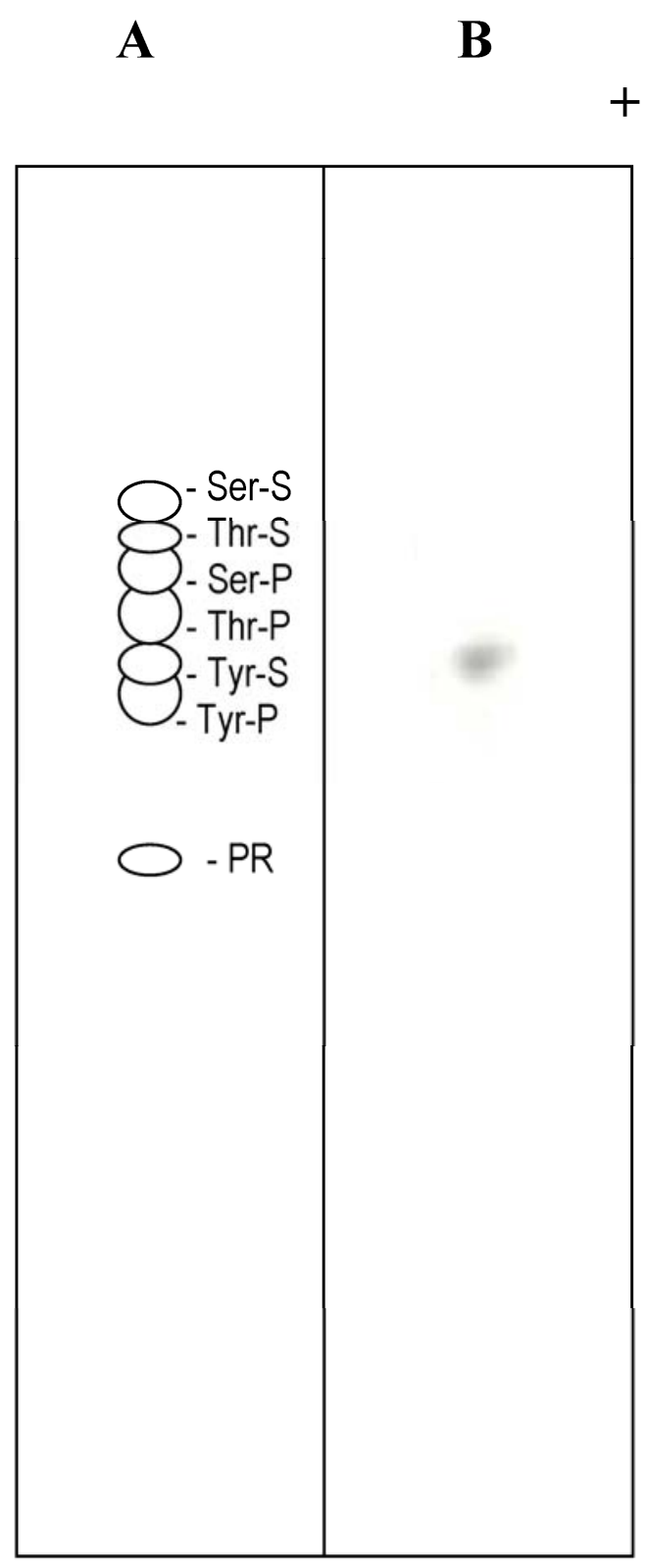

Figure 6. Thin layer electrophoresis of tyrosine sulfate. (A) Separation of non radioactive standards. The dotted lines in $\mathrm{A}$ and $\mathrm{B}$ indicate the position of tyrosine sulfate. (B). Autoradiogram of separation of an alkaline hydrolysate of sulfated statherin.

\section{Summary}

In the present study, we have demonstrated the tyrosine sulfation of statherin by the TPST present in human saliva. At present the significance of the tyrosine sulfation of statherin is not known. A possible function of tyrosine sulfation in statherin could be that it may interfere in the mineralization and demineralization process due to its binding to hydroxyapatite [20] and also in Actinomyces viscosus interactions [21]. Statherin, a 43-residue polypeptide contains 7 tyrosine residues and at least one sequence
E-Q-P-L-Y (residues 26-30) that satisfies the sequence preference for tyrosine sulfation as demonstrated by Lin et al., (11) and Bundgaard et al., [12] (Fig.7). However, the Actinomyces viscosus binding site in statherin is at the C-terminus that also contains a tyrosine residue (Q-Y-T-F). Although this segment does not contain the motif for tyrosine sulfation, the potential sulfation of Tyr 30 residue may affect the binding of statherin to A. viscosus.

\section{DSSEEKFLRRIGRFGYGYGPYQPVPEQPLYPQPYQPQYQQYTF $\prod$ \\ PP}

Figure 7. Primary structure of statherin. The potential sulfation site is underlined. Note additional tyrosines in the sequence especially at the C-terminus where A. viscosus binding may occur.

\section{Acknowledgement}

This work was supported by grant \#AA09191 from the National Institute on Alcohol Abuse and Alcoholism and by grant \# DE10538 from National institute of Dental and Craniofacial Research.

\section{Conflict of interest}

The authors have declared that no conflict of interest exists.

\section{References}

1. William S, Ramaprasad P, Kasinathan C. Purification of tyrosylprotein sulfotransferase from rat submandibular salivary glands. Arch Biochem Biophys. 1977;338:90-96

2. Slomiany BL, Liau YH, Li Q, Fekete Z, Slomiany A. Role of sulfation in post-translation processing of salivary mucins. Arch Oral Biol. 1991;36:785-790

3. Pitroski J, Murty VLN, Czajkowski A, Slomiany A, Yotsumoto F, Majka J, Slomiany BL. Association of salivary bacterial aggregating activity with sulfomucin. Biochem Mol Biol Int. 1994;32:713-721

4. Bodanszky M, Martinez J, Priestley GP, Gardner JD, Mutt V. Cholecystokinin (pancreozymin). 4. Synthesis and properties of a biologically active analogue of the C-terminal heptapeptide with epsilon-hydroxynorleucine sulfate replacing tyrosine sulfate. J Med Chem. 1978;10:1030-10305

5. Stone SR, Hofsteenge J. Kinetics of the inhibition of thrombin by Hirudin. Biochemistry 1986;25:4622-4628

6. Baeuerle PA, Huttner WB. Inhibition of N-glycosylation induces tyrosine sulfation of hybridoma immunoglobuin G. EMBO J. 1984:3:2209-2215

7. Li F, Wilkins PP, Crawley S, Weinstein J, Cummings RD, McEver RP. Post-translational modifications of recombintant P-selectin glycoprotein ligand-1 required for binding to $\mathrm{p}$-andE-selectin. J Biol Chem. 1996;271:3255-3264

8. Farzan M, Mirzabekov T, Kolchinsky P, Wyatt R, Cayabyab M, Gerard NP, Gerard C, Sodroski J, Choe H. Tyrosine sulfation of the amino terminus of CCR5 facilitates HIV-1 entry. Cell. 1999;96:667- 676

9. Hortin G, Folz R, Gordon JI, Strauss AW. Characterization of sites of tyrosine sulfation in proteins and criteria for predicting their occurrence. Biochem Biophys Res Commun. 1986;141:326-333

10. Niehrs C, Kraft M, Lee RW, Huttner WB. Analysis of the substrate specificity of tyrosylprotein sulfotransferase using 
synthetic peptides. J Biol Chem. 1990;265:8525-8532

11. Lin WH, Larsen K, Hortin GL, Roth JA. Recognition of substrates by tyrosylprotein sulfotransferase. Determination of affinity by acidic amino acids near the target sites. J Biol Chem. 1992;267:2876-2879

12. Bundgaard JR, Vast J, Rehfeld JF. New consensus features for tyrosine O-sulfation determined by mutational analysis. J. Biol. Chem. 1997;272:21700-21705

13. Ramasubbu N, Reddy MS, Bergey EJ, Haraszthy GG, Soni SD and Levine MJ. Large-scale purification and characterization of the major phosphoproteins and mucins of human submandibular-sublingual saliva. Biochem J. 1991;280:341-352

14. Huttner WB, Baeuerle PA. Protein Sulfation on Tyrosine. Modern Cell Biology. 1998;6:97-140

15. Kasinathan C, Ramaprasad P, Sundaram P. Identification and Characterization of Tyrosylprotein Sulfotransferase from Human Saliva. Int J Biol Sci. 2005;1:141-145

16. Sundaram P, Slomiany A, Slomiany BL, Kasinathan C. Tyrosylprotein sulfotransferase in rat submandibular salivary glands. Int J Biochem. 1992;24: 663-667

17. Li J, Helmerhorst EJ, Yao Y, Nunn ME, Troxler RF, Oppenheim FG. Statherin is an in vivo pellicle constituent: identification and immuno-quantification. Arch Oral Biology. 2004;49:379-385

18. Frerot O, Vargas F. Cholecystokinin activation: Evidence for an ordered reaction mechanism for the tyrosyl protein sulfotransferase responsible for the peptide sulfation. Biochem Biophys Res Commun. 1991;181:989-996

19. Lee RWH, Huttner WB. (Glu62, Ala30, Tyr8)n serves as high-affinity substrate for tyrosylprotein sulfotransferase: A Golgi enzyme. Proc Natl Acad Sci. 1985;82:6143-6147

20. Schleesinger DH, Hay DI, Levine DI. Complete primary structure of statherin, a potent inhibitor of calcium phosphate precipitation, from the saliva of monkey, Macaca arctoides. Int J Peptide Protein Res. 1989;34:374-380

21. Gibbons RJ, Hay DI. Human salivary acidic proline-rich proteins and statherin promote the attachment of Actinomyces viscosus LY7 to apatitic surfaces. Infect Immun. 1988;56:439-445 